\title{
TWELVE NEW RECORDS OF CORAL ASSOCIATED FISH FROM THE SAINT MARTIN'S ISLAND BASED ON MORPHOMETRIC AND MOLECULAR APPROACHES
}

\author{
Mst. Mashruba Naznin ${ }^{1}$, Mohammad Abdul Baki ${ }^{1}$, Md. Muzammel Hossain ${ }^{1}$, \\ Sujan Kumar Datta ${ }^{1}$ and Md. Sagir Ahmed ${ }^{1 *}$ \\ Department of Zoology, Jagannath University, Dhaka, Dhaka1100, Bangladesh
}

\begin{abstract}
The study was conducted to know the diversity of coral associated fishes of the Saint Martin Island from December 2017 to April 2019. A total of 46 coral associated marine fish species were recorded, among them 12 species; guilcheri Lutjanus, Lutjanus russellii, Parupeneus indicus, Siganus sutor, Thalassoma lunare, Gazza achlamys, Pomadasys andamanensis, Pomadasys kaakan, Lethrinus crocineus, Argyrosomus regius, Istigobius ornatus and Cryptocentrus cyanotaenia under six family were newly recorded from this Island. We assume that there are more species to be explored and need proper management strategy for conservation of coral reef and its associated biodiversity.
\end{abstract}

Key words: New records, morphology, DNA barcode, COI gene.

\section{INTRODUCTION}

The St. Martin's Island is a small island in the northeastern part of the Bay of Bengal, about $9 \mathrm{~km}$ south of the tip of the main land of Teknaf peninsula and forming the southernmost part of Bangladesh. This is the only island in Bangladesh which has the coral reefs, are described as being situated along the north-west, west and south-west coast of the island. Enormous areas of sand ridge, some mangrove formations, pandanus vegetation and scattered boulder/dead corals are the major characteristics of this island. The main attraction for any coral island is their different, varieties of multicolor ornamental fishes. The first checklist of the fishes of St. Martine Island (Tomascik 1997) included 86 species belonging to 34 families from coastal and adjacent waters. Shafi and Quddus (2003) reported 14 species belonging to 11 families. Hossain and Islam (2006) mentioned 98 species were coral associated. Rahman et al. (2009) compiled 147 species belonging to 50 families. Sarker et al. (2015) found 26 species belonging to 11 families in short survey. It is evident

*Author for corresponding: <sagir@du.ac.bd>, ${ }^{2}$ Department of Zoology, University of Dhaka, Dhaka1000, Bangladesh.

(C2020 Zoological Society of Bangladesh https://doi.org/ 10.3329/bjz.v48i2.52367 
that most of the published reports on ichthyofauna of this island is inconsistent. Ahmed et al. (2020) described the molecular characterization of 185 species of marine and coastal fishes of Bangladesh based on mitochondrial Cytochrome $\mathrm{C}$ Oxidase subunit I gene (COI). They have reported 21 species of new records. But no in-depth survey was undertaken on fish diversity, especially associated with coral reef habitat. This study describes twelve coral associated fish species based on morphometric and molecular approaches.

\section{MATERIAL AND METHODS}

Sample collection and preservation: The study was conducted at the Saint Martin's Island $\left(20^{\circ} 34^{\prime} \mathrm{N}-20^{\circ} 38.8^{\prime} \mathrm{N}\right.$ and $\left.92^{\circ} 18^{\prime} \mathrm{E}-92^{\circ} 20.8^{\prime} \mathrm{E}\right)$ from December, 2017 to April, 2019. Fish samples were collected from local fish market and landing station of Saint Martin's Island. Local fishermen caught coral associated fish using gill net, ber jal and hooks and lines. After collecting fish sample, taken photograph to get the original color pattern of fresh fish samples. Then the specimens were preserved in ice cool box till transfer at -20 ${ }^{\circ} \mathrm{C}$ in fisheries lab, Department of Zoology, Jagannath University till further morphometric and meristic analysis.

Taxonomic identification: Identification of all collected individual samples was performed following the published reference materials (Rahman et al. 2009, Allen 1985, Heemstra and Randall 1993, Humann 1994). All possible morphometric and meristic characteristics were carefully observed, measures and counted.

Molecular identification: Immediately after collecting the specimens, tissue samples were excised and stored in 90\% ethanol. Voucher specimens were fixed with $10 \%$ formalin and then transferred to $70 \%$ ethanol solution for preservation. Voucher specimens were carried and deposited in the Dhaka University Zoology Museum (DUZM).

DNA barcoding: Genomic DNA was extracted from the muscle tissue samples by the standard Proteinase-K/Phenol-Chloroform-isoamyl alcohol method (Green and Sambrook 2012, Sambrook and Russell 2001). The quality and quantity of the extracted DNA was measured using Nanodrop ${ }^{\mathrm{TM}}$ spectrophotometer. Approximately $658 \mathrm{bp}$ was amplified from the $5^{\prime}$ region of the MT-COI gene using the following primers: FishF2 5'TCGACTAATCATAAAGATATCGG CAC3' and FishR2 5'ACTTCAGGGTGACCGAAG AATCAGAA3' (Ward et al., 2005). For this, $25 \mu 1$ PCR reaction mixtures were prepared which included 17.25-18.75 $\mu 1$ of ultrapure water, $2.5 \mu 1$ of $10 \times$ PCR buffer, $1.25 \mu 1$ of $\mathrm{MgCl}_{2}(50 \mathrm{mM}), 0.25 \mu \mathrm{l}$ of 
each primer $(0.01 \mathrm{mM}), 0.125 \mu \mathrm{l}$ of each dNTP $(0.05 \mathrm{mM}), 1 \mu \mathrm{l}(0.625 \mathrm{U})$ of Taq polymerase, and 0.5-2.0 $\mu 1$ of DNA template. Amplifications were performed using ABI thermal cycler (ThermoFisher Scientific). The thermal regime consists of an initial step of $2 \mathrm{~min}$ at $95{ }^{\circ} \mathrm{C}$ followed by 35 cycles of $0.5 \mathrm{~min}$ at $94{ }^{\circ} \mathrm{C}, 0.5$ min at $54{ }^{\circ} \mathrm{C}$, and $1 \mathrm{~min}$ at $72{ }^{\circ} \mathrm{C}$, followed in turn by $10 \mathrm{~min}$ at $72{ }^{\circ} \mathrm{C}$ and then held at $4{ }^{\circ} \mathrm{C}$. PCR products were visualized on $1 \%$ agarose gel. The PCR products were purified using PureLink ${ }^{\mathrm{TM}}$ PCR purification kit and sequenced from First BASE Laboratories, Malaysia. All sequences were translated into amino acids to confirm the effectiveness of the sequences and to detect the presence of nuclear DNA pseudogenes, insertions, deletions, or stop codons. Sequences were checked and aligned using Sequencher v5.4.6 and were submitted to GenBank with referred accession numbers. All the data including taxonomic characteristics and accession numbers of GenBank were tagged with the voucher specimens preserved at the museum of Department of Zoology, University of Dhaka.

\section{RESULTS AND DISCUSSION}

In the present study, a total of 160 individuals were collected comprising of 46 species (41 upto species level and another 5 upto genus level) of coral associated fish belonging to 33 genera 26 families and 6 orders. Among 6 orders, Perciformes was dominant, which belongs to 20 families, 25 genera and 38 species. Based on morphometric and molecular characters 12 species under 10 genera were confirmed as new records from Bangladesh. Key identifying morphometric characteristics are briefly described below.

Lutjanus guilcheri Fourmanoir, 1959 (Plate A: 1)

Identifying characteristics: Dorsal profile of head steeply sloped. Pectoral fin is yellowish. Color: Body Color is red or reddish-orange. Dorsal fin is reddish, and also tip of the dorsal fin is deeply reddish. Pectoral fin is yellowish. Pelvic and anal fins are also reddish. Fin formula is D X/14; P 17; V I/6; A III/9; C 20.

\section{Lutjanus russellii (Bleeker, 1849) (Plate A: 2)}

Identifying characteristics: A black spot which is sometimes faint is on the lateral line below the anterior portions of the soft dorsal fin. Seven yellow horizontally curved stripes present on the body. Color: Generally, body whitish with silvery sheen. Head is silvery color. Seven yellow stripes present on the body. Pectoral and pelvic fin is whitish. Anal fin is yellowish in color. Caudal fin is blackish. Fin formula is D X/14; P 17; V I/5; A III/8; C 18.

\section{Parupeneus indicus (Shaw, 1803) (Plate A: 3)}

Identifying characteristics: Horizontally elongate yellow spot (sometimes partly white) on lateral line below inter-dorsal space. Round black spot as large as or 
larger than eye on side of caudal peduncle, two-thirds of which lies above the lateral line. Color: Body reddish browns dorsally, the scale edges narrowly dark, shading to whitish or pale pink ventrally. Dorsal fin is light greenish to pinkish. Pectoral, pelvic and anal fin is pinkish. Fin formula is D1 VIII; D2 9; P 16; V I/5; A I/7; C 21.

\section{Siganus sutor (Valenciennes, 1835) (Plate A: 4)}

Identifying characteristics: Many rounded white spot present on the body. Forward-projecting spine is present. Color: After preservation, body deep blackish dorsally and light is whitish ventrally. Dorsal and anal fin is blackish. Pectoral and pelvic fin is light yellowish. Caudal fin is blackish with base light yellowish. Fin formula is D XIII/10; P 16; V II/3; A VII/9; C 18.

Thalassoma lunare (Linnaeus, 1758) (Plate A: 5)

Identifying characteristics: Head green to blue with irregular pink to violet bands. Blue pectoral fins with a large elongate pink area distally. Large yellow crescent posteriorly is present in caudal fin. Color: Body dark green to blue with vertical red to purplish red lines. Head green to blue with irregular pink to violet band. Dorsal fin is bluish. Pectoral fin is blue with a large elongate pink area. Pelvic and anal fins were greenish to bluish. Yellow crescentic posteriorly present in caudal fin. Fin formula is D VIII/13; P 17; V I/5; A III/11; C 19.

Gazza achlamys Jordan \& Starks, 1917 (Plate A : 6)

Identifying characteristics: With distinct canine teeth in both jaws. Mouth is pointing forward when protracted. Scales present on the body, absent anterior to a line from origin of soft dorsal fin to behind pectoral fin bases. Color: After preservation, body surface in general silvery color, blackish dorsally and ventral silvery. Head color including nostril and above the upper lips light yellowish. Two lips color light is yellowish. Silvery is operculum. Dorsal fin is whitish, tip of spine blackish irregular marks. Membrane of spinous dorsal fin is black at its distal portion. Black dots are present all over ventral half of the body and head. Pectoral and pelvic fin is colorless. Anal fin yellow anteriorly. Caudal fin base is yellowish. Fin formula is D VIII/16; P 16; V I/5; A III/14; C 27.

\section{Pomadasys andamanensis McKay and Satapoomin, 1994 (Plate A: 7)}

Identifying characteristics: Four blackish horizontal stripes are present on the back and flanks. Soft anal fin is blackish. Color: Generally, body light silver dorsally and whitish ventrally. Head is blackish in color. Among four blackish body stripes, 1st stripe starts from slightly above the origin of spinous dorsal and join with the starting base of soft dorsal; 2nd stripe starts just below the first one and reaches upto the anterior portion of soft dorsal; 3rd stripe starts from the nape and reaches upto the last basal portion of soft dorsal fin; 4th 
stripe starts from just behind the eye, run along the eye and reaches upto the base of caudal fin. All the fins are blackish without pectoral fin, which is brownish in color. Fin formula is D XII/16; P 17; V I/5; A III/9; C 20.

\section{Pomadasys kaakan (Cuvier, 1830) (Plate A: 8)}

Identifying characteristics: Spots and blotches on the dorsal fin and the bands of double spots or blotches on the body. Large individuals may lose the body spots. Color: The body is silver dorsally and whitish ventrally with a golden tint on the sides. It has seven pairs of dark spots arranged into vertical interrupted bars on the upper sides The head is olive yellowish and the snout is blackish. The spinous part of the dorsal fin is white with a black membrane tip. Two rows of black spots are found in the inter-membranous portion of the 3rd spine to the 10th spine, and one black spot between the 10th and 11th spine. The soft part is white and bordered with black. The pectoral fin is brownish, and the basal $1 / 3$ portion is reddish. The pelvic and anal fins are whitish. The caudal fin is whitish at the basal half and blackish at the rest half toward the tip. Fin formula is D1 XII/14; P 16; V I/5; A III/8; C 17.

\section{Lethrinus crocineus Smith, 1959 (Plate A: 9)}

Identifying characteristics: Pectoral fin is yellowish. Dorsal and caudal fin's tip reddish. Color: Body light blackish dorsally, whitish ventrally. Head is greenish. Dorsal fin, anal fin and caudal fin are reddish. Pectoral fin is yellowish. Fin formula is D X/; P 13; V I/5; A III/9; C 19.

\section{Argyrosomus regius (Asso, 1801) (Plate A: 10)}

Identifying characteristics: Rough scales present. Mouth is protractile with caniniform teeth. Color: In general, body and all the fins blackish in color. Fin formula is D X/29; P 19; V I/5; A II/8; C 17.

\section{Istigobius ornatus (Rüppell, 1830) (Plate A: 11)}

Identifying characteristics: Five vertical rows of white spots present on pectoral fins. Blue spot present on the body and a series of black bar mid of the body. Color: Body color pale gray; operculum with 5 small blue spots interspersed with brownish red spots; 5 vertical rows of white spots on pectoral fins; anterior tip of first dorsal fin bright yellow. Fin formula is D VII/11; P 19; V 6; A I/9; C 12.

\section{Cryptocentrus cyanotaenia (Bleeker, 1853) (Plate A: 12)}

Identifying characteristics: Eleven blue band on the body and small numerous blue line on head. 4 brownish stripes present on the anal fin. Color: Body brownish grey color with 11 vertical narrow whitish blue lines on the sides; largely greenish yellow on head and mandible; head and base of pectoral fin with numerous short blue oblique broken lines and spots with markings on the head 

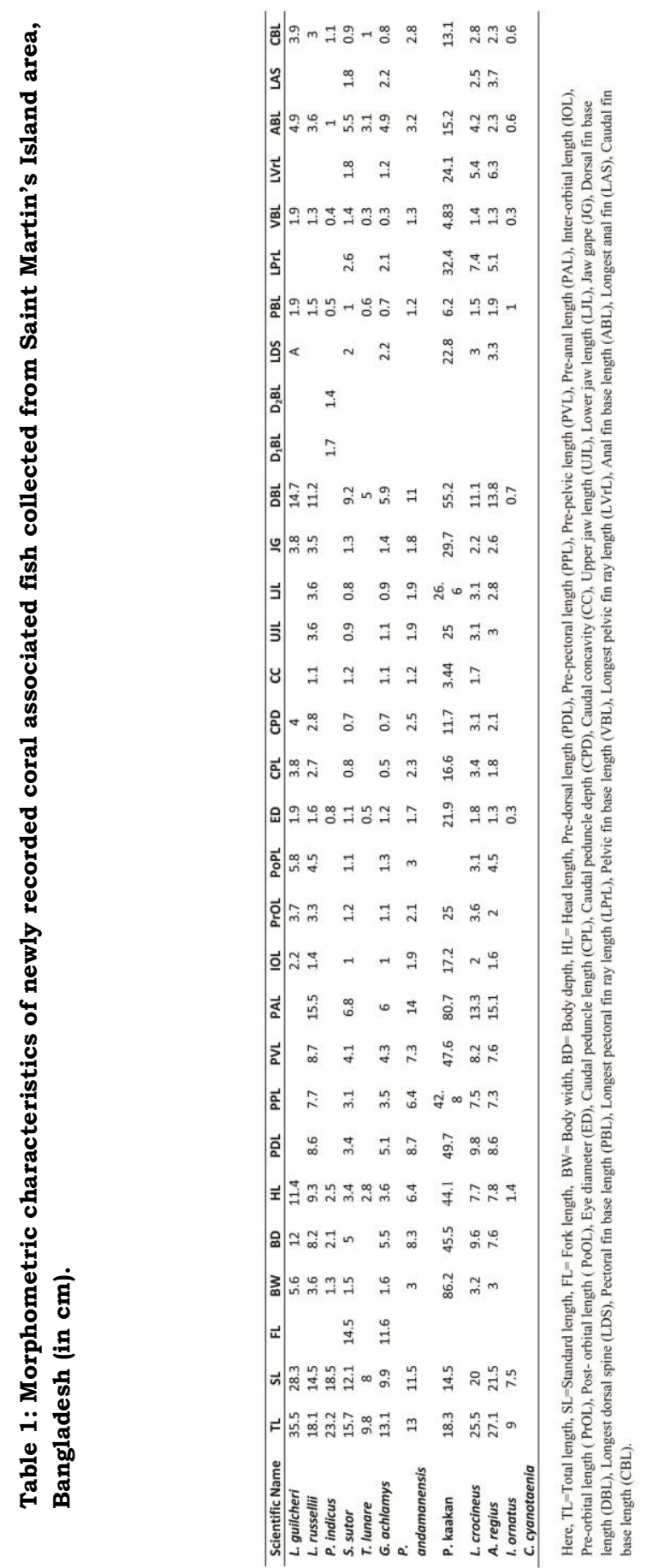


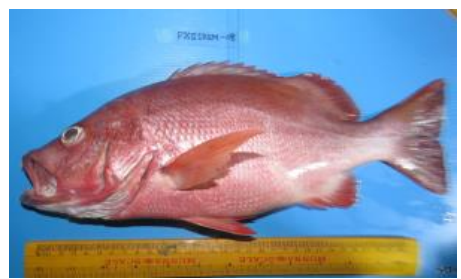

1

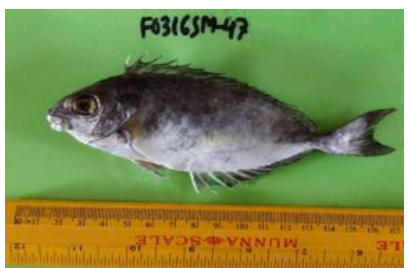

4

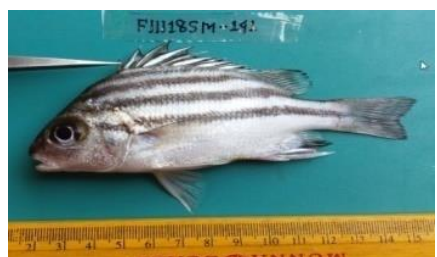

7

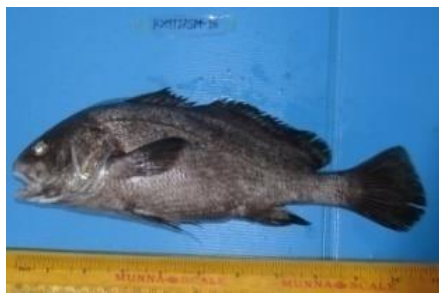

10

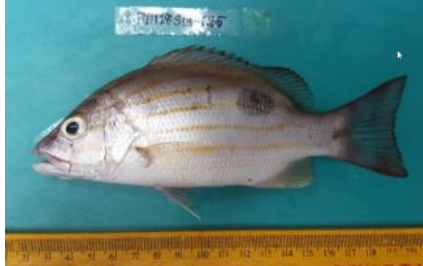

2

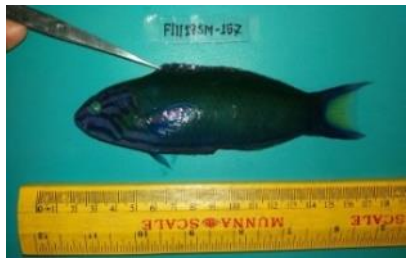

5

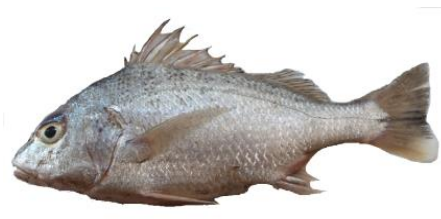

8

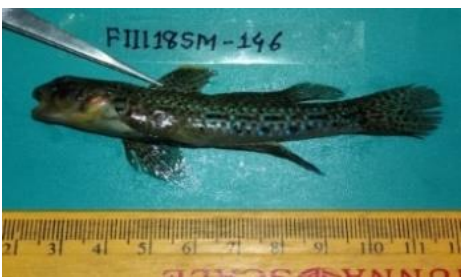

11

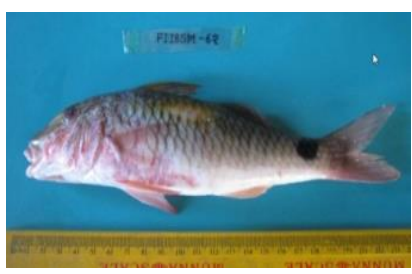

3

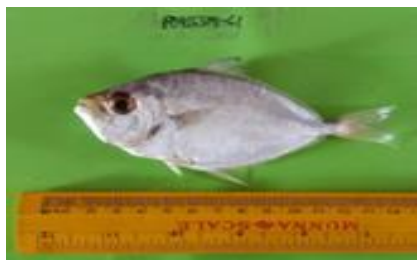

6

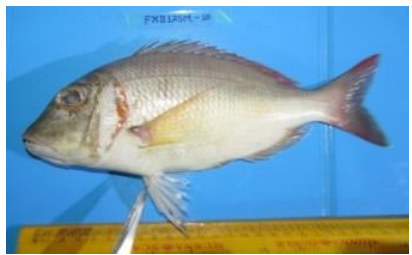

9

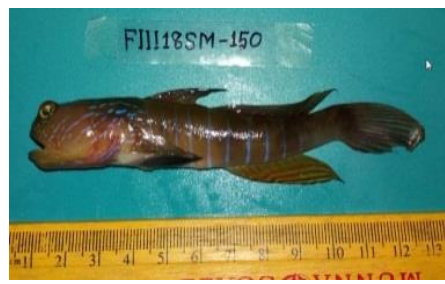

12

Plate A. 1. Lutjanus guilcheri; 2. Lutjanus russellii; 3. Parupeneus indicus; 4. Siganus sutor; 5. Thalassoma lunare; 6. Gazza achlamys; 7. Pomadasys andamanensis; 8. Pomadasys kaakan; 9. Lethrinus crocineus; 10. Argyrosomus regius; 11 . Istigobius ornatus; 12. Cryptocentrus cyanotaenia

and snout; 4-5 diffuse dark bars on side of head; yellow margin on 1 st and $2^{\text {nd }}$ dorsal fin; several longitudinal dark, orange and yellow stripes on anal fin; yellow edges on anal and caudal fin; pelvic slightly darkish violet and finely dotted with dark, pectorals hyaline and dotted with dark.

Molecular identification: As a promising alternative to the traditional species identification based on morphological characters, partial cytochrome c oxidase 
Table 2. Species of new records barcoded base of COI gene along with their GB Accessions number

\begin{tabular}{lllcl}
\hline Order & Family & Species & $\begin{array}{c}\text { No. of } \\
\text { individual }\end{array}$ & GB Accession Number \\
\hline Perciformes & Mullidae & Parupeneus indicus & 1 & MT012679 \\
& Siganidae & Siganus sutor & 3 & MH429334 MH882461 \\
& Haemulidae & Pomadasys kaakan & 1 & MH311286, NW509666 \\
& Lethrinidae & Lethrinus crocineus & 1 & MH429360 \\
& Sciaenidae & Argyrosomus regius & 1 & MH429361 \\
& Gobiidae & Istigobius ornatus & 1 & MT012661 \\
& Gobiidae & $\begin{array}{l}\text { Cryptocentrus } \\
\text { cyanotaenia }\end{array}$ & 1 & MT012659 \\
\hline
\end{tabular}

subunit I (COI) sequences (DNA barcodes) have been suggested for standardized and routine species identification (Hebert et al. 2003). Partial sequences of COI gene of seven species (Parupeneus indicus, Siganus sutor, Pomadasys kaakan, Lethrinus crocineus, Argyrosomus regius, Istigobius ornatus and Cryptocentrus cyanotaenia were generated. BLAST results showed $98-100 \%$ identity with preexisting sequences in the NCBI GenBank. Sequences were submitted to the Gen Bank and accordingly assigned GB Accession numbers which validated their taxonomic identification (Table 2).

Teleost fishes are an important component of coral reef ecosystems, fulfilling many critical ecological roles (McClanahan 2000; Bellwood et al. 2004; Dulvy et al. 2004), and are a major source of food and livelihood for people in tropical coastal areas (Pauly et al. 2002). The extent of habitat damage and initial reef condition will also influence fish responses to disturbance. It is often assumed that the relationship between coral cover and fish diversity is linear (Bell and Galzin 1984). In the coral reef ecosystem, reef fish diversity is an important indicator to assessment reef ecology. In the studies, we have recorded 46 coral reefs associated marine fish that is helpful for further extension research on ecology and fish diversity. All reef fish species have significant value in fishery, tourism, local economy, nutrition, socio-economic activities and biodiversity.

Acknowledgments: We acknowledge the financial support from the Ministry of Science and Technology, Government of the People's Republic of Bangladesh as a grant for Special Allocation in Research (2016-2017). 


\section{LITERATURE CITED}

AHMED, M. S., DATTA, S., SAHA, T., and HOSSAIN, Z. 2020. Molecular characterization of marine and coastal fishes of Bangladesh through DNA barcodes. Authorea Preprints. June 2020. DOI: 10.22541/au.15188549.94742267. 1-10.

ALLEN, G. R. 1985. FAO Species Catalogue Vol 6. Snappers of the World. An annotated and illustrated catalogue of lutjanid species known to date. FAO Fish Synop. 125, 208.

BELL, J. D. and GALZIN R. 1984. Influence of live coral cover on coral-reef fish communities. Mar Ecol Prog Ser 15:265-274.

BELlWOOD, HUGHES, T.P., FOLKE, C., and NYSTROM M. 2004. Confronting the coral reef crisis. Nature 429:827-833.

DULVY, N.K., FRECKLETON, R.P., POLUNIN, N.V.C. 2004. Coral reef cascades and the indirect effects of predator removal by exploitation. Ecol Lett 7:410-416.

GREEN, M.R. and SAMBROOK, J. 2012. Molecular Cloning: A Laboratory Manual. 4th Ed.Vol. 1. New York: Cold Spring Harbor Laboratory Press; pp. 2-80.

HEEMSTRA, P. C. and RANDALL, J. E. 1993. FAO Species Catalogue. Groupers of the world (family Serranidae, subfamily Epinephelinae). An annotated and illustrated catalogue of the grouper, rockcod, hind, coral grouper and lyretail species known to date. Rome: FAO. FAO Fish. Synop. 125 (16):382 p.

HOSSAIN, M. M. and ISLAM, H. 2006. Status of The Biodiversity of Saint Martin's Island, Bay of Bengal, Bangladesh. Pak. J. of Mari. Sci. 15(2): 201-210 p.

HUMANN, P. 1994. Reef fish identification: Florida, Caribbean, Bahamas. New World Publications, Jacksonville, Florida. 426 p.

HEBERT ,P .D .CYWINSKA ,A .and BALL ,S .L .2003 .Biological identifications through DNA barcodes. Proc. Biol. Sci. , $R$. Soc 270 .(1512): 313-321p.

MCCLANAHAN, T. R. 2000. Recovery of a coral reef keystone predator, Balistapus undulatus, in East African marine parks. Biol Conserv 94:191-198.

PAUlY, D., CHRISTENSEN, V., GUENETTE, S., PITCHER, T. J., RASHID SUMAILA, U.,

WALTERS, C.J., WATSON, R., and ZELLER, D. 2002. Towards sustainability in world fisheries. Nature 418:689-695.

RAHMAN, A. K. A., KABIR, S. M. H., AHMED, M., AHMED, A. T. A., AHMED, Z. U. M. BEGUM, Z. N. T., HASAN, M. A. and KHONDKER, M. (eds.), 2009. Encyclopedia of Flora and Fauna of Bangladesh. Marine fishes. Asiatic Society of Bangladesh. Dhaka. 24:485 p.

SARKER, M. M., BAKI, M. A. and SARKER, A., 2015.Taxonomic study of coral fish of Saint Martin's Island in the Bay of Bengal (Abstract). Marine conservation and Blue economy Symposium, 2015. Krishibid Institution of Bangladesh, Dhaka.

SAMBROOK, J. and RUSSELL D.W. 2001. Molecular cloning: a laboratory manual,3rd edn. Press, New York, Cold Spring Harbor Lab 2344 pp 
SHAFI M. and QUDDUS M.M.A. 2003. Fisheries Resources in the Bay of Bengal. Kabir publication, 38/3 Bangla Bazar, Dhaka. 150 pp.

TOMASCIK, T. 1997. Management plan for coral resources of Narikel jinjira (St. Martin's Island), national conservation strategy implementation project-1, Ministry of Environment and Forest, Government of Bangladesh. 126 pp.

WARD, R. D., ZEMLAK, T. S. and INNES, B. H. 2005. Barcoding Australia's fish species. Phil. Trans.

R. Soc. London B 360:1847-1857 p.

(Manuscript received on 20 September, 2020 revised on 25 December, 2020) 